it has alone the theoretical advantage of in- leukaemia-a very rare coincidence. Blood ducing immune tolerance, ${ }^{1}$ has a suppressive was taken from the patient a day after effect on experimental autoimmune disease, ${ }^{2}$ leukaemia was diagnosed. Lymphocytes were and is more effective than other alkylating separated as described by Hughes and agents in suppressing antibody production. ${ }^{3}$ Caspary, ${ }^{1}$ the procedure taking about $2 \frac{1}{2}$

Accepting the fact that patients may be hours. The patient was admitted again for too few for a controlled trial, I feel that obstetric reasons at 38 weeks and the baby patients given treatment of this type should was born four days later. Blood was taken have frequent scientific assessment of the immediately from the umbilical cord and an activity of their disease. In the case of S.L.E. hour later from the mother. A third specimen one might expect a record of frequent of blood was taken from the mother three estimations of $\alpha_{2}$-globulins, complement weeks later. From all samples of blood components, cryoglobulins, serum DNA, and lymphocytes were separated and embedded RNA antibodies, as well as L.E. cells and with the same procedure as described in antinuclear factor.-I am, etc.,

E. N. WARDLE

Wellcome Research Laboratories,

Royal Victoria Infirmary,

1 Dukor, P., and Dietrich, F. M., International Archives of Allergy, 1968, 34, 32 .

Gerebtzoff, A., Lambert, P. H., and Miescher, P. A Annual Review of Pharmacology, 1972, $12,287$.

emmell, E., Hurd, E. R., and Ziff, M., Clinical and Experimental Immunology, 1971, 8, 355.

\section{Treatment of Systemic Lupus} Erythematosus

SIR,-With reference to the report by Dr. M. L. Snaith and his colleagues (28 April, p. 197) concerning the choice of immunosuppressive drugs in systemic lupus erythematosus, our experience has been that the marrow-depressant effect of azathioprine when used in the treatment of rheumatoid arthritis in a dose of $2.5 \mathrm{mg} / \mathrm{kg} / \mathrm{day}$ or cyclophosphamide in a dose of $1.5 \mathrm{mg} / \mathrm{kg} /$ day has been relatively easily controlled with adequate monitoring of the blood, including platelet counts.

An important difference, however, has been the effect of cyclophosphamide on fertility in the male. We found that six male patients on azathioprine had entirely normal sperm counts. In contrast, of six males on cyclophosphamide, five were found to be azoospermic and one had a count of only 5 million $/ \mathrm{ml}$. If chlorambucil produced amenorrhoea in four of six patients in Dr. Snaith's series, it seems likely that its effect on fertility is similar to that of cyclophosphamide.

We would suggest, therefore, that there are strong grounds for first considering azathioprine when an immunosuppressive agent is indicated in young patients with connective tissue disorders.-We are, etc.

Michael Mason A. M. BROWNJOHN JACQUELINE HARRIS JOHN WOODLAND

The London Hospital

London E.1

\section{Surface Particles on Leukaemic Lymphocytes}

SIR,-In a previous letter (20 January, p. 172) I reported the presence of surface particles on leukaemic lymphocytes from five cases of chronic lymphatic leukaemia and one of acute leukaemia.

After this report had been published a patient aged 41 who was 26 weeks pregnant was diagnesed as having chronic lymphatic detail elsewhere. ${ }^{2}$

Membrane blebs on the surface of the lymphocytes were a striking feature of the first sample of maternal blood (fig. 1).

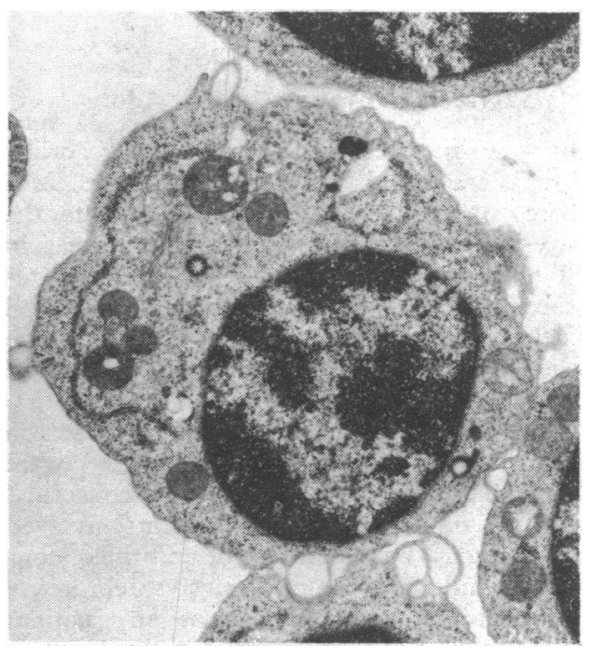

Though these blebs were present on the surface of lymphocytes in the second and third samples they did not appear to be as common as in the first. Most of the lymphocytes from the second sample contained granular dense structures similar to those of polymorphs. In all three samples from the mother, besides the blebs, particles were seen budding from the surface of the lymphocytes and a few were free, as described in my previous letter (figs. 1 and 2).

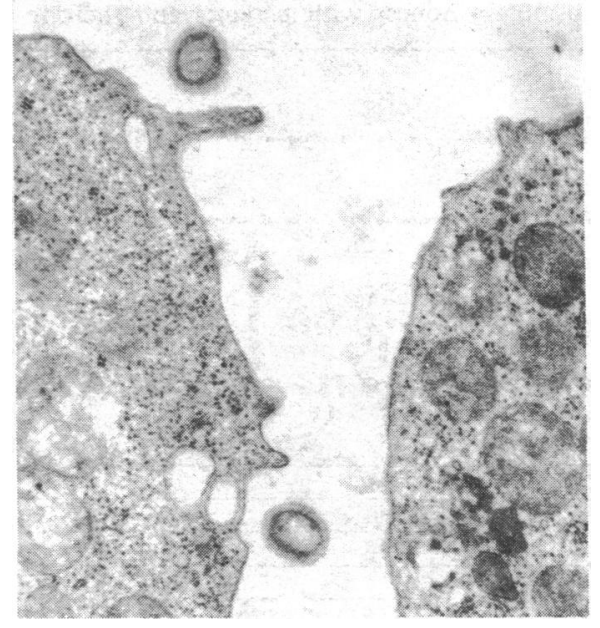

Lymphocytes from the umbilical cord blood appeared quite normal, though they showed pseudopodia; they did not have blebs or particles similar to those in the lymphocytes of the mother (fig. 3).

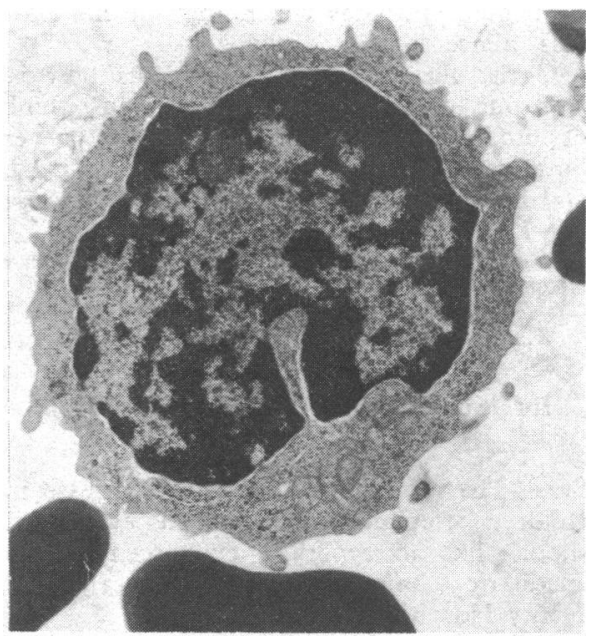

It has been thought that surface blebs might be artefacts due to the fixation and embedding technique, but the present study clearly indicates the presence of surface blebs and particles in the lymphocytes of the mother with chronic lymphatic leukaemia, as in the other six leukaemic patients studied, while their absence from the lymphocytes from the cord blood and from those of normal subjects does indicate their relationship to the disease. It must be borne in mind that the random sampling variations in the electron microscope may easily give a misleading assessment of the frequency with which a particular structure is encountered, and that this difficulty is increased by the possibility of artefacts even in seemingly "well fixed" material. Although 10 times more lymphocyte blocks were cut from the cord blood sample than from the samples from the mother, there was no evidence that maternal lymphocytes are to be found in the blood of the child.

I would like to thank Dr. F. Clark for his courtesy in allowing access to his patients. -I am, etc.

Demyelinating Diseases Unit,

H. K. NARANG Medical Research Council,

Newcastle General Hospita

1 Hughes, D., and Caspary, E. A., International Archives of Allergy, 1970 , 37, 506.
2 Narang, H. K. Fournal of Hygiene, 1973. In press.

FIG. 1-Lymphocytes from 41-year-old leukaemic patient 26 weeks pregnant. Note the surface blebs and particles. $x 11,240$

FIG. 2-Lymphocytes from the same patient showing two free virus-like particles. $x$ 19,35s.

(w). blood of $x 8,765$

\section{Mute of Malady}

SIR,-With reference to your leading article (31 March, p. 755), elucidation of the underlying cause of mutism may be helped by demonstration of thought content. This may confirm a diagnosis of schizophrenic or depressive stupor and can be helpful in the management of elective mutism and some conversion symptoms.

A time-honoured method of achieving this in adults is by amylobarbitone sodium abreaction. I Investigators of mute patients, however, are understandably reluctant to administer a powerful central nervous system depressant to patients who may have grave organic brain damage or be suffering from drug effects. Intravenous diazepam has been 